\title{
Impact of genetic variation on metabolic response of bone to diet
}

\author{
Siobhán Cusack ${ }^{1 *}$ and Kevin D. Cashman ${ }^{1,2 *}$ \\ ${ }^{1}$ Department of Food and Nutritional Sciences and ${ }^{2}$ Department of Medicine, University College, Cork, Republic of Ireland
}

\begin{abstract}
There is compelling evidence to suggest that both the development of bone to peak bone mass at maturity and subsequent loss depend on the interaction between genetic, hormonal, environmental and nutritional factors. The major part $(\leq 80 \%)$ of the age-specific variation in bone turnover and bone density is genetically determined. However, the notion of genetic determinant is of little value unless the specific genes that are involved can be identified. Most work in this area of osteoporosis research has focused on the candidate gene approach, which has identified several candidate genes for osteoporosis, including genes encoding the vitamin D receptor (VDR), oestrogen receptors ( $\alpha$ and $\beta$ ), apolipoprotein E, collagen type I $\alpha 1$ and methylenetetrahydrofolate reductase, amongst many others. However, in general, findings from numerous studies of the association between such genes and various bone variables have been inconsistent. In addition to possible gene-gene interactions it is likely that there are interactions between these genes and certain environmental factors, especially nutrition, that may mediate expression of bone-related phenotypes. While these potential interactions add a level of complexity to our understanding of these apparent genetic effects on bone, identification of a role for genetic factors without knowledge of their interaction with nutrients can do little to advance prevention and treatment of osteoporosis. This information is especially important because, unlike genotype, diet and nutrition can be modified. The aim of the present review is to critically evaluate current knowledge relating to candidate genes for osteoporosis, with particular emphasis on their interaction with nutrients and dietary factors in determining bone health.
\end{abstract}

\section{Osteoporosis: Genotype: Nutrient: Interactions}

Osteoporosis is a metabolic bone disease characterized by low bone mass and deterioration of bone tissue that leads to bone fragility and an increase in fracture risk in later life. Ageing demographics of Europe and other continents suggest that unless drastic measures are taken to prevent the development of osteoporosis, the incidence and the costs associated with treating osteoporosis will climb in the coming decades (Norris, 1992; European Commission, 1998), posing a major socio-economic burden. Consequently, the urgent need for suitable preventive strategies has intensified osteoporosis research carried out by physicians as well as scientists from a diverse range of backgrounds. While the molecular genetics of osteoporosis and the role of nutrition in bone health are currently very vibrant and important research areas in their own right, there is a huge opportunity for more collaborative research efforts between these two areas aimed at cohesive strategies for osteoporosis prevention.

The importance of genetics in the pathogenesis of osteoporosis is well established. Studies in twins and families have shown that genetic factors play an important role in the regulation of bone mineral density (BMD) and other determinants of osteoporotic fracture risk. It has been estimated from twin studies that $50-85 \%$ of the variance in BMD is genetically determined (Pocock et al. 1987; Christian et al. 1989; Slemenda et al. 1991). Family-based studies have also yielded strong heritability estimates for BMD, especially in young adulthood (Gueguen et al. 1995). Whilst low $\mathrm{BMD}$ is a major risk factor for osteoporotic fracture, there are other determinants of osteoporotic fracture risk, including femoral neck geometry and hip axis length, ultrasound properties of bone, biochemical markers of bone turnover, BMI, age at menarche and age at menopause, and these factors also have a heritable component (for review, see Stewart \& Ralston, 2000). For example, heritability estimates of risk factors such as quantitative ultrasound, femoral neck geometry and markers of bone turnover range between 50 and $80 \%$ (Arden et al. 1996; Garnero et al. 1996).

\footnotetext{
Abbreviations: Apo, apolipoprotein; BMD, bone mineral density; HRT, hormone-replacement therapy; MTHFR, methylenetetrahydrofolate reductase; OR, oestrogen receptor; VDR, vitamin D receptor.

*Corresponding author: Professor Kevin D. Cashman, fax +353 21 4270244, email k.cashman@ ucc.ie
} 
Osteoporosis is a complex disease that is mediated by an interaction between environmental factors (including nutrition, smoking and physical activity) and several different genes that individually have modest effects on BMD and other aspects of fracture risk (Gueguen et al. 1995). However, the notion of genetic determinants is of little value unless the specific genes involved can be identified and the interactions between these genes and certain environmental factors (especially nutrition) that may mediate expression of bone-related phenotypes can be elucidated.

\section{Strategies for identification of osteoporosis-susceptibility genes}

There are several strategies for identification of genes that are involved in the pathogenesis of polygenic disorders, including osteoporosis. These strategies include linkage analysis studies, studies investigating allele sharing in sibling pairs and the candidate gene approach, amongst others; the advantages and disadvantages have been described in detail elsewhere (Stewart \& Ralston, 2000; Thompson, 2001; Vink \& Boomsma, 2002; Ralston, 2003). In essence, all these approaches involve looking for evidence of an association between a phenotypic characteristic (e.g. bone turnover, BMD, fractures) and a single or series of polymorphic genetic marker(s) (Stewart \& Ralston, 2000). The genetic markers used in these studies are polymorphic regions of DNA, which are analysed by polymerase chain reaction-based techniques on DNA extracted usually from peripheral blood. There are two main types of marker, repeat polymorphisms of variable length (e.g. dinucleotide repeats) and single nucleotide polymorphisms. Genetic studies involve typing a large number of markers spread at regular intervals throughout the genome (a genome-wide search) or typing markers that are concentrated in specific areas of interest (candidate loci) or in specific genes of interest (candidate genes; Stewart \& Ralston, 2000). Genetic linkage studies have been successful in defining several loci responsible for regulation of bone mass, and now these chromosomal regions are being mined, or fine mapped, for genes contained therein that may predispose to low BMD. Studies using the osteoporosis candidate gene approach, on the other hand, have logically tackled the main regulators of bone metabolism and mass. While the potential interaction between such genes and environmental factors, including nutrients and food components, add a level of complexity to our understanding of these apparent genetic effects (see p. 905), identification of a role for genetic factors without knowledge of such interactions can do little to advance prevention and treatment of osteoporosis (Wood \& Fleet, 1998). The remainder of the present review will briefly describe the various candidate genes for susceptibility to osteoporosis that have been most extensively investigated, and then review available evidence for interactions between these genes and certain nutrients or food components in determining bone health, and thus osteoporosis risk.

\section{Candidate genes for osteoporosis}

There have been a staggering number of studies published over the last two decades that have reported associations, or lack thereof, between candidate genes and bone turnover, BMD and/or fracture incidence, as well as other bonerelated phenotypic characteristics such as ultrasound properties of bone. These genes encode a wide range of proteins, including receptors for calciotrophic and steroid hormones, bone matrix proteins, and local regulators of bone metabolism, such as cytokines and growth factors, amongst others (see Table 1). Some of the more important candidate genes that have been studied (especially genes for which a gene-nutrient interaction is likely or possible) are discussed in more detail later.

Table 1. Major candidate genes implicated in the aetiology of osteoporosis

\begin{tabular}{|c|c|c|c|}
\hline Candidate gene & Bone health-related function & Physiological correlate & Seminal reference(s) \\
\hline Vitamin D receptor & $\begin{array}{l}\text { Ca absorption; osteoblast and } \\
\text { osteoclast activity }\end{array}$ & $\begin{array}{l}\text { BMD, Ca absorption, bone } \\
\text { turnover }\end{array}$ & $\begin{array}{l}\text { Morrison et al. (1994), Gross } \\
\text { et al. (1996) }\end{array}$ \\
\hline Oestrogen receptor $\alpha$ & Osteoblast and osteoclast activity & BMD, fracture & $\begin{array}{l}\text { Sano et al. (1995), Kobayashi } \\
\text { et al. (1996) }\end{array}$ \\
\hline Oestrogen receptor $\beta$ & Osteoblast and osteoclast activity & BMD & Ogawa et al. (2000) \\
\hline Collagen type I $\alpha 1$ & Matrix compoenent & BMD, fracture, bone quality & Grant et al. (1996) \\
\hline MTHFR enzyme & Homocysteine clearance & $\mathrm{BMD}$, fracture & Miyao et al. (2000) \\
\hline TGF $\beta 1$ & Osteoblast and osteoclast activity & $\mathrm{BMD}$, vertebral fracture & Langdahl et al. (1997) \\
\hline Androgen receptor & Osteoblast function & BMD & Sowers et al. (1999) \\
\hline Interleukin 6 & Osteoclast activity & BMD & Murray et al. (1997) \\
\hline Apolipoprotein E & Vitamin $\mathrm{K}$ transport & $\begin{array}{l}\text { BMD, hip and wrist fracture } \\
\text { bone quality }\end{array}$ & Shiraki et al. (1997) \\
\hline PTH receptor & $\begin{array}{l}\text { Ca homeostasis; osteoblast and } \\
\text { osteoclast activity }\end{array}$ & BMD & Hosoi et al. (1999) \\
\hline Calcitonin receptor & Osteoclast function & BMD, vertebral fracture & Masi et al. (2002) \\
\hline Osteocalcin & Matrix component & BMD & Dohi et al. (1998) \\
\hline Ca-sensing receptor & Regulation of $\mathrm{Ca}$ homeostasis & BMD & Takacs et al. (2002) \\
\hline Metalloproteinase- 1 & Matrix component & BMD & Yamada et al. (2002) \\
\hline
\end{tabular}

BMD, bone mineral density; MTHFR, Methylenetetrahydrofolate reductase; TGF $\beta-1$, transforming growth factor $\beta 1$; PTH, parathyroid hormone. 


\section{Vitamin D receptor gene polymorphisms}

The majority of association studies of BMD and candidate gene markers have investigated markers in the vitamin D receptor (VDR) gene (Wood \& Fleet, 1998). The secosteroid 1,25-dihydroxycholecalciferol has been shown to be an important hormonal regulator of bone and Ca metabolism (Norman et al. 1990) and the VDR mediates the biological actions of 1,25-dihydroxycholecalciferol. Thus, the prominent role of the VDR in Ca metabolism made the VDR gene a likely candidate gene in determining low BMD and, hence, risk of osteoporosis. While there are likely to be more than twenty-five polymorphisms present in the VDR gene, including areas that are functionally relevant such as the promoter region (Uitterlinden et al. 2002), most associational studies to date have focused on only a handful of these polymorphisms.

Taq 1, Bsm 1 and Apa 1 vitamin D receptor polymorphisms. In 1994 a cardinal study by Morrison et al. (1994) reported a significant association $(P<0 \cdot 0001-P<0.05$, depending on skeletal site) between polymorphic sites situated between exons 8 and 9 at the $3^{\prime}$ end of the VDR gene (detected using the Bsm 1 restriction enzyme) and BMD in 250 Caucasian twins aged 17-70 years from Australia. The study consisted of seventy monozygotic and fifty-five dizygotic adult twin pairs; with most subjects being female. In addition, a further 311 unrelated healthy adult females (207 of which were postmenopausal) were also studied. From their study of twins Morrison et al. (1994) concluded that much of the genetic variation in BMD $(\leq 75 \%)$ could be explained on the basis of the Bsm 1 VDR genotype alone. They also reported that post-menopausal women with the $B B$ VDR genotype would reach the BMD 'fracture threshold' (defined as 2 SD below the mean of young adults) 10 years sooner than their $b b$ VDR genotype counterparts. This greater decline in BMD in the $B B$ VDR group could markedly increase their risk of bone fracture. However, the same group subsequently reported that there were problems with their original genotyping of the dizygotic twin part of their study, such that the heritability component attributable to the VDR is lower (Morrison et al. 1997).

Since the initial report by Morrison et al. (1994) many groups have investigated the relationship between VDR genotypes (defined at the $3^{\prime}$ end) and BMD and bone turnover (as measured by serum- and urinary-based biochemical markers) either in twins or in general populations. Although many studies in Caucasian and Asian populations have confirmed a positive effect between extreme homozygotes (i.e. $B B v . b b$ ), other studies have reported little or no effect in various populations (for reviews, see Eisman, 1995, 1999, 2001; Peacock, 1995; Wood \& Fleet, 1998; Gennari et al. 2002; Uitterlinden et al. 2002). Moreover, some studies, including a large Dutch study, have reported a VDR gene allele effect, but in the opposite direction to that of the previous studies (Houston et al. 1996; Salamone et al. 1996; Uitterlinden et al. 1996). After reviewing sixteen studies published up to July 1996 in a meta-analysis, Cooper \& Umbach (1996) concluded that although overall there was an effect of the Bsm 1 VDR polymorphism (of the order of about $0.3 \mathrm{SD}$ ) between alternate homozygotes), it was weaker than that reported in the original study of Morrison et al. (1994; a difference of $\leq 1$ $\mathrm{SD}$ unit, or $10 \%)$. A second more recent meta-analysis of seventy-five studies published (in full or as abstracts) between 1994 and 1998 confirmed the findings of the earlier meta-analysis, concluding that there was strong evidence for a positive effect of VDR on bone mass (Gong et al. 1999).

Some of the inconsistencies in the various studies performed to date may arise from the VDR gene effects on bone being modified by dietary $\mathrm{Ca}$, vitamin $\mathrm{D}$, caffeine and possibly the intake of other nutrients (see p. 905), or by an interaction of the VDR gene with other genes such as the oestrogen receptor (OR) $\alpha$ gene (Gennari et al. 1998; Willing et al. 1998; Deng et al. 1999; for review, see Gennari et al. 2002).

There is also some, albeit inconsistent, evidence to suggest a relationship between VDR genotype and other bone-related phenotypic characteristics such as $\mathrm{Ca}$ absorption (see p. 903) and fracture. For example, there are only a limited number of studies that have investigated the link between VDR genotype and fracture incidence, the clinically-relevant outcome of osteoporosis; three studies found a positive association (Feskanich et al. 1998; Langdahl et al. 2000; Uitterlinden et al. 2001), while other studies found no effect (Berg et al. 1996; Houston et al. 1996; Ensrud et al. 1999).

Studies that have sought to define a functional association for the 3'-VDR polymorphisms using reporter gene constructs and gene transcription assays, or in vitro binding assays, have yielded mixed results (Morrison et al. 1994; Verbeek et al. 1997; Gross et al. 1998a; for reviews, see Gennari et al. 2002; Uitterlinden et al. 2002).

Fok 1 VDR polymorphisms. Another common polymorphism in the VDR gene has been described in the coding region (exon 2; Gross et al. 1996; Arai et al. 1997). This polymorphism results in a $\mathrm{T} \rightarrow \mathrm{C}$ transition, recognized by the Fok 1 restriction enzyme. It creates an alternative translation start codon ( $9 \mathrm{bp}$ downstream) that results in a shorter isoform of the VDR gene. The Fok 1 polymorphism in the VDR gene has been associated with a $13 \%$ lower lumbar spine BMD and a greater rate of bone loss at the hip (4.7 v. $0.5 \%$ for ff $v$. FF genotypes) in post-menopausal Mexican-American women (Gross et al. 1996). However, no intergroup differences were detected in any of the biochemical indices of bone turnover (Gross et al. 1996). The Fok 1 polymorphism has been associated with BMD in some studies reported subsequently (Miyamoto et al. 1996; Arai et al. 1997; Harris et al. 1997; Gennari et al. 1999; Lucotte et al. 1999; Choi et al. 2000), but not others (Eccleshall et al. 1998; Cheng \& Tsai, 1999; Sowers et al. 1999; Tofteng et al. 2002). This polymorphism does not seem to be in linkage dysequilibrium with $3^{\prime}$-VDR polymorphisms, and thus acts independently.

In a study in children aged 7-12 years Ames et al. (1999) showed that the Fok 1 polymorphism at the VDR translation initiation site was associated with BMD and $\mathrm{Ca}$ absorption. Children with the $F F$ genotype absorbed on average $115 \mathrm{mg}$ $\mathrm{Ca} / \mathrm{d}$ more than those with the ff genotype. BMD was $8.2 \%$ greater in the $F F$ genotype than in the $f f$ genotype. These results suggest a substantial relationship between the VDR gene and bone health at one or more levels, including absorption of dietary $\mathrm{Ca}$ and $\mathrm{BMD}$ in growing children. It 
should be noted, however, that the influence of the Fok 1 VDR genotype has not been found in all studies of children and young adults. Ferrari et al. (1998), for example, failed to find an association between the Fok 1 VDR polymorphism and BMD in European-Caucasian prepubertal girls and premenopausal women.

As with the studies of the $3^{\prime}$ polymorphisms, functionality studies of the Fok 1 polymorphism have yielded mixed results (Arai et al. 1997; Gross et al. 1998b; for reviews, see Gennari et al. 2002; Uitterlinden et al. 2002). Thus, there is a need for further work to define the molecular mechanisms by which the various VDR polymorphisms influence $\mathrm{Ca}$ metabolism and bone mass.

\section{Oestrogen receptor ( $\alpha$ and $\beta$ ) gene polymorphisms}

Oestrogen deficiency in post-menopausal women is associated with increased bone turnover and acceleration of bone loss, leading to increased susceptibility to bone fractures (Nguyen et al. 1995). Furthermore, oestrogen-replacement therapy has been shown to prevent this accelerated bone loss, which is associated with the post-menopausal period (Riggs \& Melton, 1986). The presence of the OR has been demonstrated in human bone cells, suggesting that oestrogen may exert a direct effect on bone. Moreover, an inactivating mutation of the $\mathrm{OR} \alpha$ gene has been associated with decreased bone density in the case of a male patient (Smith et al. 1994), and there has also been a report of decreased BMD values in mice lacking functional OR $\alpha$ (Korach, 1994). Thus, it is not surprising that research has focused on the possible relationships between polymorphisms at the OR $\alpha$ locus and bone mass. Similarly, while the exact role of the OR $\beta$ is not clear, its involvement in mediating an oestrogenic action on bone growth and size in OR $\beta$ knock-out mice (Windahl et al. 1999) has made it another likely candidate gene.

Oestrogen receptor a gene polymorphisms. Sano et al. (1995) reported a positive association between a TA dinucleotide repeat polymorphism in the OR $\alpha$ promoter and bone mass in a study of 144 Japanese women. Sowers et al. (1999) reported similar findings from a study of an American population (including 261 pre- and perimenopausal women). There have also been a number of studies that have investigated associations between haplotypes defined by $P v u$ II and/or Xba I restriction fragment length polymorphisms in the first intron of the OR $\alpha$ gene and bone mass. While some of these studies reported positive associations between the $P v u$ II and/or Xba I polymorphisms and bone mass (Kobayashi et al. 1996; Mizunuma et al. 1997; Ongphiphadhanakul et al. 1998), other studies did not (Han et al. 1997; Gennari et al. 1998; Vandevyver et al. 1999). An association between OR $\alpha$ genotype and low BMD has also been found in Caucasian populations (Mahonen et al. 1997; Willing et al. 1998). However, in these studies low BMD was shown to be associated with the $p p \mathrm{OR} \alpha$ genotype, while in Asian populations low BMD is associated with the PP OR $\alpha$ genotype, suggesting that the $\mathrm{OR} \alpha$ genotype effect on BMD may be population specific (Willing et al. 1998). A recent meta-analysis of data from studies published up to November 2001, encompassing data for 5834 female subjects from thirty distinct study groups, found no association between the $P v u$ II polymorphism and BMD, while $X X$ OR $\alpha$ genotype, detected by use of the $X b a$ I restriction enzyme, was found to confer a higher BMD, in addition to a protective effect that decreased the risk of fracture (Ioannidis et al. 2002).

The molecular mechanism by which these polymorphisms influence bone mass is unclear. Both $P v u$ II and $X b a$ I polymorphisms lie in an apparently non-functional area of the gene (Stewart \& Ralston, 2000).

Oestrogen receptor $\beta$ gene polymorphisms. Ogawa et al. (2000) reported an association between BMD and a dinucleotide (CA) repeat polymorphism located in the flanking region of the OR $\beta$ gene in healthy Japanese postmenopausal women. Lau et al. (2002) also found an association between the OR $\beta$ and BMD in premenopausal Chinese women, but with a different allelic distribution pattern, i.e. twenty-six-CA repeats $v$. twenty-CA repeats in the studies of Ogawa et al. (2000) and Lau et al. (2002) respectively were associated with significantly $(P<0 \cdot 01)$ increased lumbar spine adjusted BMD values. Ban et al. (2001) failed to find an association between either the twenty-CA repeat allele or twenty-six-CA repeat allele and BMD in a population of older Japanese women. Functional studies will also be required to unravel the underlying molecular mechanisms of these polymorphisms.

\section{Apolipoprotein E gene polymorphisms}

Apolipoprotein E (Apo E) is a major constituent of HDL and LDL. The Apo E protein is polymorphic, and structural variants have been detected by isoelectric focusing. There are three common alleles in the population $(\in 2, \in 3$ and $\in 4)$ at a single gene locus (human chromosome 19), which produce the gene products Apo E2, E3 and E4 respectively (Mahley et al. 1991). This polymorphism results in six common Apo E phenotypes, three homozygous (E2/2, E3/3 and E4/4) and three heterozygous (E4/2, E4/3 and E3/2). The Apo E3/3 phenotype is the most common, occurring in $>60 \%$ of individuals (Simopoulos, 1995). Thus, Apo E3 is considered the parent form of this protein, while Apo E4 and Apo E2 are its variants and are themselves distinguished by single amino acid substitutions at residues 112 (cysteine $\rightarrow$ arginine) and 158 (arginine $\rightarrow$ cysteine) respectively of the 299-amino acid chain that constitutes mature Apo E (de Knijff et al. 1994).

Apo E allelic frequencies vary among populations. For example, when compared with most Caucasian populations the $\in 4$ allele is more prevalent in Finns $(23 v .15 \%)$ and the $\in 3$ allele is more prevalent in the Japanese (85 v. $75 \%$; Hegle \& Breslow, 1987).

Shiraki et al. (1997) investigated the relationship between phenotypes of Apo E and BMD in 284 post-menopausal Japanese women. The Apo E phenotype groupings were defined as Apo E4-/- (i.e. E3/2 and E3/3; $76 \%$ of the population), Apo E4+/- (i.e. E4/2 and E4/3; $22 \%$ of the population) and Apo E4+/+ (i.e. E4/4; $2 \%$ of the population). A significant $(P<0.05)$ gene-dose effect from the Apo E4 allele on BMD of the lumbar spine and total body was reported. Subjects in the Apo E4/4 phenotype group had the lowest BMD and a higher bone turnover, as indicated by 
higher serum levels of intact osteocalcin (Shiraki et al. 1997). Several other studies have reported an association between BMD and the Apo E4 genotype (Sanada et al. 1998; Dick et al. 2002; Pluijm et al. 2002). Salamone et al. (2000) found that peri- and post-menopausal women (not taking hormone-replacement therapy (HRT)) with an Apo E4 allele had a two-fold higher rate of spinal bone loss compared with those without an Apo E4 allele, an allelic effect not observed in women on HRT. Interestingly, Cauley et al. (1999) found that American-Caucasian women with at least one of the Apo E4 alleles were at a substantially increased risk of hip and wrist fractures that was not explained by bone density, impaired cognitive function or falling. However, it should be noted that some studies have found no association between the Apo $\mathrm{E}$ genotype and BMD, bone loss and/or osteoporotic fracture (Booth et al. 2000; Heikkinen et al. 2000; Stulc et al. 2000; von Muhlen et al. 2001).

The reason for the observed relationship between the Apo E genotype and BMD, bone loss and/or fracture incidence in some studies but not in others is unclear, but it may be related to a gene-nutrient interaction between the Apo E genotype and vitamin K status (see p. 907).

\section{Methylenetetrahydrofolate reductase gene polymorphism}

Miyao et al. (2000) recently demonstrated that an allelic polymorphism in the gene encoding the methylenetetrahydrofolate reductase (MTHFR) enzyme, which is important in clearing homocysteine from the circulation, was associated with reduced BMD in post-menopausal Japanese women. The polymorphism is located at nucleotide 677 in the MTHFR gene and is caused by a single base change $(\mathrm{C} \rightarrow \mathrm{T})$, leading to an amino acid replacement of alanine with valine at position 222 . This point mutation gives rise to a thermo-labile variant of the MTHFR enzyme that is less effective. Abrahamsen et al. (2003) also reported that early post-menopausal Danish women with the TT MTHFR genotype had significantly lower BMD at the hip $(P<0.01)$ and lumbar spine $(P<0.05)$ and increased fracture incidence $(P<0.05)$ than those with the $C C$ MTHFR genotype. However, the MTHFR genotype did not influence bone turnover, as assessed by biochemical markers in this population (Abrahamsen et al. 2003). In contrast, Jorgensen et al. (2002) reported an association between the C677T polymorphism (TT) in the MTHFR gene and a reduced risk of osteoporotic fracture of the forearm and hip in a case-control study of Danish post-menopausal women relative to those with the wild-type $C C$ genotype, even though BMD at the forearm and ultrasound variables measured at the calcaneus were similar for both genotype groups. The MTHFR genotype is associated with higher plasma homocysteine levels (Abrahamsen et al. 2003), which could affect collagen maturation and possibly bone strength. In a preliminary investigation of the data from the Aberdeen-based Prospective Osteoporosis Screening Study there was no effect of the MTHFR genotype on BMD in peri-menopausal and early post-menopausal Scottish women (S New, personal communication). The reason for the discordant findings of studies investigating the relationship between MTHFR genotype and BMD is unclear, but it may be related to B-vitamin status (see p. 906).

\section{Other osteoporosis-susceptibility genes}

In addition to the genes described earlier, a polymorphism in the gene encoding collagen type I $\alpha 1$ has been shown to be important for the genetic regulation of bone mass. For example, Grant et al. (1996) reported that a $\mathrm{G} \rightarrow \mathrm{T}$ polymorphism in the first intron of the promoter region of the collagen type I $\alpha 1$ gene, at a recognition site for the transcription factor $S p 1$, is related to bone mass and osteoporotic fracture. Furthermore, a recent meta-analysis of the numerous subsequent studies (Mann \& Ralston, 2003), which examined the relationship between the collagen type I $\alpha 1 S p \quad 1$ genotype and BMD and osteoporotic fracture, concluded that $S p 1$ alleles are associated with a modest reduction in BMD and a significantly $(P<0.01)$ increased risk of osteoporotic fracture, particularly vertebral fractures. Polymorphisms in genes encoding transforming growth factor $\beta$, androgen receptor, calcitonin receptor, osteocalcin, parathyroid hormone receptor, Ca-sensing receptor and interleukin-6, amongst others, have also been associated with bone turnover and/or BMD (see Table 1) in a limited number of studies. These studies have been reviewed elsewhere (Stewart \& Ralston, 2000; Garnero et al. 2002; Gennari et al. 2002; Uitterlinden et al. 2002; Langdahl et al. 2003) and are beyond the scope of the present review.

\section{Interaction of genotype and diet}

Understanding how inherited factors interact with environmental factors (especially nutrition) may hold the key to better prevention and treatment of osteoporosis. However, to date the number of studies that have investigated possible interactions between genotypes and nutrients or food components are limited. These studies will be reviewed in the following section.

\section{Vitamin D receptor genotype-calcium interactions}

In recent years convincing evidence has emerged concerning the association between dietary $\mathrm{Ca}$ and bone health in all age-groups (Institute of Medicine, 1997; European Commission, 1998; Cashman, 2002). Considering the important regulatory role of 1,25-dihydroxycholecalciferol in $\mathrm{Ca}$ homeostasis, which is mediated by the VDR, studies investigating the interaction between VDR genotype, $\mathrm{Ca}$ intake and bone integrity were among the first to test gene-nutrient interactions in determining bone health. Two longitudinal studies have investigated a relationship between VDR genotype, $\mathrm{Ca}$ intake and change in BMD. One study in older subjects found that while those with the higher bone density (i.e. $b b$ VDR genotype) maintained bone density, those with the lower bone density (i.e. $B B$ VDR genotype) lost bone density, irrespective of $\mathrm{Ca}$ intake (Ferrari et al. 1995). Interestingly, the bone density of the heterozygotes $(B b)$ responded to $\mathrm{Ca}$ intake, crossing from net loss to net gain at an intake of about $1000 \mathrm{mg} / \mathrm{d}$ (Ferrari et al. 1995). In contrast, Krall et al. (1995) reported 
that $\mathrm{Ca}$ supplementation of a diet habitually low in $\mathrm{Ca}$ reduced bone loss from the femoral neck in women with the $B B$ VDR genotype. Greater rates of bone loss under conditions of low dietary $\mathrm{Ca}$ intakes would be consistent with a possible effect of the VDR genotype on vitamin D-dependent $\mathrm{Ca}$ absorption (see p. 906). Moreover, this absorption defect might be masked in subjects with high $\mathrm{Ca}$ loads via a vitamin D-independent pathway (Sheikh et al. 1988).

A limited number of associational studies have examined whether dietary $\mathrm{Ca}$ influences the relationship between VDR genotype and bone, and the results have been inconsistent. For example, Kiel et al. (1997) showed that the association between $\mathrm{Ca}$ intake and BMD was dependent on VDR genotype in 69-90-year-old women. They reported that there was an association between usual $\mathrm{Ca}$ intake and $\mathrm{BMD}$ in women with the $b b$ VDR genotype, such that BMD was significantly $(P<0 \cdot 05)$ higher in those with dietary $\mathrm{Ca}$ intakes of $>800 \mathrm{mg} / \mathrm{d}$ compared with those with intakes of $<500 \mathrm{mg} / \mathrm{d}$. This association was not evident in women with the $B b$ or $B B$ VDR genotypes. Ferrari et al. (1998) reported that a trend for an association between Fok 1 VDR genotype and BMD was more evident at high $\mathrm{Ca}$ intake than at low $\mathrm{Ca}$ intake in a study of European-Caucasian females. Similarly, the association between VDR genotype and BMD at the femoral neck appeared to be modified by $\mathrm{Ca}$ intake in premenopausal women (Salamone et al. 1996). However, Garnero et al. (1996) failed to find an association between VDR genotype, BMD and Ca intake in a group $(n$ 268) of elderly post-menopausal women. However, only sixty-four of the women had a low habitual Ca intake $(<600 \mathrm{mg} / \mathrm{d})$.

There have been a number of studies that have investigated the impact of VDR genotype on Ca absorption. DawsonHughes et al. (1995), for example, compared fractional Ca absorption in healthy late post-menopausal women with the $b b$ and $B B$ VDR genotypes. Ca absorption and plasma 1,25-dihydroxyvitamin $\mathrm{D}$ levels were measured in sixty women after 2 weeks on a high $\mathrm{Ca}(1500 \mathrm{mg} / \mathrm{d})$ intake and 2 weeks on a low $\mathrm{Ca}(<300 \mathrm{mg} / \mathrm{d})$ intake. ${ }^{45} \mathrm{Ca}$ absorption was similar in the two groups on the high $\mathrm{Ca}$ intake but differed significantly $(P<0.05)$ in the groups on the low $\mathrm{Ca}$ intake (21 and $24 \%$ increases in the $B B$ and $b b$ groups respectively). $\mathrm{Ca}$ restriction induced similar percentage increases in plasma 1,25-dihydroxycholecalciferol levels, but the $B B$ group had a smaller increase in the fractional ${ }^{45} \mathrm{Ca}$ absorption index, which would be consistent with a possible intestinal resistance to the action of 1,25-dihydroxycholecalciferol. Similarly, Wishart et al. (1997) investigated the relationship between intestinal Ca absorption, serum 1,25dihydroxyvitamin D levels and all three 3'-VDR gene polymorphisms. The $b b, a a, T T$ VDR haplotype was associated with significantly $(P<0.05)$ higher $\mathrm{Ca}$ absorption. Zmuda et al. (1997) reported that African-American women (aged $\geq 65$ years) with the $B B$ genotype tended to have lower fractional ${ }^{45} \mathrm{Ca}$ absorption (by $14 \%$ ) compared with women with the $b b$ genotype. Ames et al. (1999) showed that the Fok 1 VDR genotype was associated with major differences in $\mathrm{Ca}$ absorption ( $42 \%$ between the extreme homozygotes) as well as bone density in young children. In contrast, Kinyamu et al. (1997) found no relationship between VDR polymorphisms and intestinal $\mathrm{Ca}$ absorption in either young or elderly women. Likewise, Francis et al. (1997) investigated the association between the VDR genotype and Ca absorption in men. The results showed no significant difference in $\mathrm{Ca}$ absorption among the VDR genotypes. Interestingly, despite apparent differences in intestinal $\mathrm{Ca}$ absorption, at least in some studies, two separate but small studies did not identify any genotype-related differences in intestinal VDR level (Barger-Lux et al. 1995; Kinyamu et al. 1997), suggesting that the intestine is not the primary mediator of any genotyperelated differences. VDR polymorphisms have been reported to have effects on parathyroid gland regulation (Carling et al. 1995, 1997; Yokoyama et al. 1998), suggesting differences in parathyroid hormone regulation as a possible pathway for subtle differences in vitamin $\mathrm{D}$ regulation of bone and $\mathrm{Ca}$ homeostasis.

\section{Vitamin D receptor genotype-cholecalciferol interactions}

There is compelling evidence for a protective role for vitamin D on bone health (for reviews, see Institute of Medicine, 1997; Zitterman, 2003). The response of bone to dietary vitamin D (i.e. cholecalciferol) may be modified by VDR genotype. For example, Graafmans et al. (1997) studied the effects of a 2-year regimen of vitamin D supplementation $(10 \mu \mathrm{g} / \mathrm{d})$ on BMD in Caucasian (Dutch) women $>70$ years old. They observed that the mean increase in $\mathrm{BMD}$ in the vitamin $\mathrm{D}$ group relative to the placebo group was higher in subjects with the $B B$ and $B b$ VDR genotype compared with those with the $b b$ VDR genotype.

\section{Vitamin D receptor genotype-caffeine interactions}

In addition to an effect of VDR genotype on the response of bone to $\mathrm{Ca}$ and vitamin $\mathrm{D}$, there is also some evidence for an interaction between VDR genotype and caffeine intake in determining bone loss. Rapuri et al. (2001) showed that post-menopausal women with the $t t$ genetic variant of VDR appeared to be at a greater risk for the deleterious effect of a high caffeine intake $(>300 \mathrm{mg} / \mathrm{d})$ on vertebral bone loss over 3 years compared with women with the TT VDR genotype.

\section{Methylenetetrahydrofolate reductase genotype-B-vitamin complex}

As mentioned previously the association between the common allelic MTHFR (C677T) polymorphism and BMD has been found to be variable in post-menopausal women. Some of the discordant findings on its effect on bone may arise from a possible gene-nutrient interaction between one or more of the B-vitamin complex and the MTHFR genotype. The MTHFR enzyme and several of the Bvitamin complex are required for clearing homocysteine from the circulation. A preliminary investigation of possible interactions between BMD, the MTHFR genotype and the B-vitamin complex in peri-menopausal and early postmenopausal women in the Aberdeen Prospective Osteoporosis Screening Study suggested that folate and vitamins $\mathrm{B}_{12}$ and $\mathrm{B}_{6}$ had no effect on $\mathrm{BMD}$ in the three MTHFR-genotype groups (S New, personal communication). However, for women homozygous for the $T T$ 
genotype only (the group with elevated plasma homocysteine levels), there was a positive relationship between energy-adjusted riboflavin intake and BMD. The effect of B-vitamin status, MTHFR genotype and bone integrity in older post-menopausal women, in whom homocysteine levels would be greater, and in other age-groups in both men and women needs to be investigated.

\section{Apo E genotype-vitamin $K$ interactions}

Apo E phenotype may be linked to osteoporosis and fracture risk (Shiraki et al. 1997; Sanada et al. 1998; Cauley et al. 1999; Salamone et al. 2000; Dick et al. 2002; Pluijm et al. 2002) through its involvement in the metabolism and transport of vitamin $\mathrm{K}$, an important cofactor for the carboxylation of osteocalcin (Vermeer et al. 1995). Several studies have reported an association between undercarboxylated osteocalcin, a status indicator for vitamin $\mathrm{K}$, and loss of BMD and/or hip fracture (for review, see Institute of Medicine, 2001). Genetically-determined subtypes of Apo E play a crucial role in the transport of chylomicrons, and thus of vitamin $\mathrm{K}$, to the liver and other target tissues, including bone. Saupe et al. (1993), for example, reported that the serum level of vitamin $\mathrm{K}$ depended on the Apo $\mathrm{E}$ phenotype, i.e. E2 $>\mathrm{E} 3>\mathrm{E} 4$. This distribution is in accordance with the relationship between the Apo E genotype and the rate of hepatic clearance of chylomicron remnants from circulation, with the Apo E4 allele having the most rapid catabolism (Booth et al. 2000). This finding may have implications for the supply of vitamin $\mathrm{K}$ to bone cells for metabolic activity. In the only study to date that has investigated the relationship between vitamin $\mathrm{K}$, the Apo $\mathrm{E}$ geno-type and bone Booth et al. (2000) failed to find evidence of an interaction between vitamin $\mathrm{K}$ intake and the Apo E4 allele in relation to BMD or fracture incidence in elderly men and women. In that study there was no association between either vitamin $\mathrm{K}$ intake or Apo $\mathrm{E}$ genotype and BMD or fracture, even though several studies have reported relationships between the intake and/or status of vitamin $\mathrm{K}$ and bone outcomes (Institute of Medicine, 2001) and the Apo E genotype and bone outcomes (Shiraki et al. 1997; Sanada et al. 1998; Cauley et al. 1999; Salamone et al. 2000; Dick et al. 2002; Pluijm et al. 2002). Vitamin $\mathrm{K}$ intake was estimated by a food-frequency questionnaire and, unfortunately, data on vitamin $\mathrm{K}$ status (such as undercarboxylated osteocalcin) were unavailable. Future studies will need to include measures of the Apo E genotype, vitamin $\mathrm{K}$ intake and status, and bone variables in order to test the hypothesis that vitamin $\mathrm{K}$ may mediate the observed relationship between Apo E genotype and hip fracture.

\section{Possible oestrogen receptor genotype-phyto-oestrogen interactions}

While the mechanism by which polymorphisms in the OR $\alpha$ gene affect BMD is unclear, it may be that they confer some extent of oestrogen resistance. For example, Han et al. (1997) suggest that variants in the OR $\alpha$ gene might account for the lack of response to HRT in some women despite good drug compliance and good health. If the $\mathrm{OR} \alpha$ genotype can lead to oestrogen resistance, then there are also implications for women using dietary phyto-oestrogens as a natural alternative to HRT. Phyto-oestrogens are nonsteroidal compounds that occur naturally in foods of plant origin (especially soyabean foods), and they are able to compete with the principal oestrogens of most mammals (17 $\beta$-oestradiol and oestrone) to bind with OR (Cassidy, 1996). Such compounds have been shown to have a favourable effect on bone mass in post-menopausal women in several, but not all, studies (Dalais et al. 1998; Potter et al. 1998; Morabito et al. 2002; for review, see Cotter \& Cashman, 2003). Although post-menopausal HRT is, and dietary phyto-oestrogen supplementation appears to be, effective in preventing bone loss, individual variation exists in relation to the response to HRT and phyto-oestrogen supplementation (Hassager et al. 1994; Dalais et al. 1998; Potter et al. 1998; Salmen et al. 2000b; Morabito et al. 2002). For example, some studies have reported that spinal BMD is diminished in 3-30\% of the women who take accepted bone-sparing doses of oestrogen (Genant et al. 1982; Riis et al. 1987; Stevenson et al. 1990). It has also been reported that $\leq 11 \%$ of the healthy early postmenopausal women who receive HRT over $\geq 1$ year lose $>1 \%$ bone/year (Hassager et al. 1994; Han et al. 1997). Post-menopausal women who are not receiving HRT lose on average $2 \%$ of BMD annually (European Commission, 1998). There is also variation between individuals in their skeletal response to dietary phyto-oestrogen supplementation (Dalais et al. 1998; Potter et al. 1998; Morabito et al. 2002). This variation could be explained by a geneticallydetermined response to HRT and phyto-oestrogen therapy.

Several studies have investigated the influence of the OR $\alpha$ genotype, singly and in relation to the VDR genotype, on the responsiveness of bone to HRT in post-menopausal women. Recently, Ongphiphadhanakul et al. (2000) reported that the OR $\alpha$ gene polymorphism (as defined by the $P v u$ II endonuclease system) affects the vertebral BMD response to oestrogen in post-menopausal women, suggesting that OR $\alpha$ genotype may help identify those women who will have more skeletal benefit from oestrogen therapy. Similarly, Salmen et al. (2000a) suggested that women possessing a $P$ allelle (as defined by the $P v u$ II endonuclease system for detecting the OR $\alpha$ genotype) would benefit more from longterm HRT than those without this allele. Han et al. (1997), on the other hand, reported that after 1 year of HRT the changes in bone density in post-menopausal women were not associated with the OR $\alpha$ genotype.

To date, no studies have investigated the influence of the OR $\alpha$ genotype on the responsiveness of bone to dietary phyto-oestrogen supplementation. Furthermore, phytooestrogens, which have been shown to have a relative molar binding affinity for OR $\alpha$ between 100 and 1000 times lower than that for $17 \beta$-oestradiol in vitro (Kuiper et al. 1998), have an even higher specificity for OR $\beta$ (Mosselman et al. 1996). OR $\beta$ is preferentially expressed in tissues such as bone, brain, vascular endothelia and bladder. However, to date, no studies have investigated the influence of the OR $\beta$ genotype on the responsiveness of bone to phyto-oestrogen supplementation. Since dietary phyto-oestrogens bind to both $\mathrm{OR} \alpha$ and $\mathrm{OR} \beta$, polymorphisms in both receptor subtypes may influence the response of bone to phyto- 
oestrogen therapy. However, future research is needed to investigate the potential impact of genetic variation at the OR genes loci on the responsiveness of bone to phytooestrogen therapy.

\section{Conclusion}

While numerous candidate genes for osteoporosis susceptibility have been identified over the last two decades, in general it appears that individually several of these genes have modest effects on BMD and other aspects of fracture risk. It is not surprising that numerous genes have been implicated in osteoporosis, considering the number of regulatory proteins involved in $\mathrm{Ca}$ and bone metabolism, as well as other aspects of bone strength and quality. Furthermore, the complexity of osteoporosis is mediated, at least in part, by an interaction between environmental factors and many of these candidate genes. There is increasing evidence that the effects of some of these genes on bone health-related variables are modified by certain nutrients and other dietary components. While there has been some interest in this specific research area in recent years, it is likely that interactions between genetic and nutritional factors are an important target for future research. Considering the number of metabolic pathways by which the nutrient environment can influence bone health, it is highly likely that allelic variation in other known, and yet to be discovered, osteoporosis-susceptibility genes will be shown to interact with nutritional factors in terms of determining an effect on bone. Without doubt, diet-bone health studies that adopt this 'nutrigenetic' approach will be complicated by the potential effects of gene-gene interactions and undefined environmental factors. On the other hand, consideration of nutritional factors, as well as other environmental factors such as alcohol and exercise, will be critical in interpreting these genetic pathways and in the development of genotype-specific, or 'individuallytailored', nutritional recommendations for bone health. To this end, nutritional scientists researching in the area of dietgene interactions in bone health might be well advised to keep a close eye on developments in the pharmaceutical sector, in particular the 'pharmacogenetic' $v$. 'pharmacogenomic' approach to drug therapy. While pharmacogenetics is aimed at optimization of drug therapy based on an individual patient's genetic profile, i.e. individual single nucleotide polymorphisms, pharmacogenomics utilizes information from multiple single nucleotide polymorphisms within a patient's genome to maximize efficacy and minimize toxicity of drug therapy. This sector is also carefully considering the important bioethical issues that surround this type of research. Thus, with time it may be possible that 'nutrigenomics' will replace, or at least complement, research currently being carried out in the area of nutrigenetics and bone health.

\section{Acknowledgement}

This work was carried out with financial support from the European Commission Quality of Life Fifth Framework Programme. QLK1-CT 1999-000752.

\section{References}

Abrahamsen B, Madsen JS, Tofteng CL, Stilgren L, Bladbjerg EM, Kristensen SR, Brixen K \& Mosekilde L (2003) A common methylenetetrahydrofolate reductase (C677T) polymorphism is associated with low bone mineral density and increased fracture incidence after menopause: longitudinal data from the Danish osteoporosis prevention study. Journal of Bone and Mineral Research 18, 723-729.

Ames SK, Ellis KJ, Gunn SK, Copeland KC \& Abrams SA (1999) Vitamin D receptor gene Fok I polymorphism predicts calcium absorption and bone mineral density in children. Journal of Bone and Mineral Research 14, 740-746.

Arai H, Myamoto K, Taketani Y, Yamamoto H, Iemori Y, Morita K, Tonai T, Nishisho T, Mori S \& Takeda E (1997) A vitamin D receptor gene polymorphism in the translation initiation codon: effect on protein activity and relation to bone mineral density in Japanese women. Journal of Bone and Mineral Research 12, 915-921.

Arden NK, Griffiths GO, Hart DJ, Doyle DV \& Spector TD (1996) The association between osteoarthritis and osteoporotic fracture: the Chingford study. British Journal of Rheumatology 35, 1299-1304.

Ban Y, Tozaki T, Taniyama M, Tomita M \& Ban Y (2001) Lack of association between estrogen receptor ER $\beta$ dinucleotide repeat polymorphism and autoimmune thyroid diseases in Japanese patients. BioMed Central Medical Genetics 2, 1.

Barger-Lux MJ, Heany RP, Hayes J, DeLuca HF, Johnson ML \& Gong G (1995) Vitamin D receptor gene polymorphism, bone mass, body size, and vitamin D receptor density. Calcified Tissue International 60, 491-495.

Berg JP, Falch JA \& Haug E (1996) Fracture rate, pre- and postmenopausal bone mass and early and late postmenopausal bone loss are not associated with vitamin D receptor genotype in a high-endemic area of osteoporosis. European Journal of Endocrinology 135, 96-100.

Booth SL, Tucker KL, Chen H, Hannan MT, Gagnon DR, Cupples LA, Wilson PW, Ordovas J, Schaefer EJ, DawsonHughes B \& Kiel DP (2000) Dietary vitamin K intakes are associated with hip fracture but not with bone mineral density in elderly men and women. American Journal of Clinical Nutrition 71, 1201-1208.

Carling T, Kindmark A, Hellman P, Lundgren E, Ljunghall S, Rastad J, Akerstrom G \& Melhus H (1995) Vitamin D receptor genotypes in primary hyperparathyroidism. Nature Medicine $\mathbf{1}$, 1309-1311.

Carling T, Ridefelt P, Hellman P, Rastad J \& Akerstrom G (1997) Vitamin D receptor polymorphisms correlate to parathyroid cell function in primary hyperparathyroidism. Journal of Clinical Endocrinology and Metabolism 82, 1772-1775.

Cashman KD (2002) Calcium intake, calcium bioavailability and bone health. British Journal of Nutrition 87, Suppl. 2, S169-S177.

Cassidy A (1996) Physiological effects of phyto-oestrogens in relation to cancer and other human health risks. Proceedings of the Nutrition Society 55, 399-417.

Cauley JA, Zmuda JM, Yaffe K, Kuller LH, Ferrell RE, Wisniewski SR \& Cummings SR (1999) Apolipoprotein E polymorphism: A new genetic marker of hip fracture risk - The study of osteoporotic fractures. Journal of Bone and Mineral Research 14, 1175-1181.

Cheng WC \& Tsai KS (1999) The vitamin D receptor start codon polymorphism (Fok I) and bone mineral density in premenopausal women in Taiwan. Osteoporosis International 9, 545-549.

Choi YM, Jun JK, Choe J, Hwang D, Park SH, Kang D, Kim JG, Moon SY \& Lee JY (2000) Association of the vitamin D receptor start codon polymorphism (Fok I) with bone mineral density in 
post-menopausal Korean women. Journal of Human Genetics 45, 280-283.

Christian JC, Yu PL, Slemenda CW \& Johnston CC Jr (1989) Heritability of bone mass: a longitudinal study in aging male twins. American Journal of Human Genetics 44, 429-433.

Cooper GS \& Umbach DM (1996) Are vitamin D receptor polymorphisms associated with bone mineral density? A metaanalysis. Journal of Bone and Mineral Research 11, 1841-1849.

Cotter A \& Cashman KD (2003) Genistein, a soy-based dietary phytoestrogen, appears to prevent early postmenopausal bone loss as effectively as hormone replacement therapy. Nutrition Reviews (In the Press)

Dalais F, Rice G \& Wahlqvist M (1998) Effects of dietary phytoestrogens in postmenopausal women. Climateric 1, 124-129.

Dawson-Hughes B, Harris SS \& Finneran S (1995) Calcium absorption on high and low calcium intakes in relation to vitamin D receptor genotype. Journal of Clinical Endocrinology and Metabolism 80, 3657-3661.

de Knijff P, van den Maagdenberg AM, Frants RR \& Havekes LM (1994) Genetic heterogeneity of apolipoprotein E and its influence on plasma lipid and lipoprotein levels. Human Mutation 4, 178-194.

Deng HW, Li J, Li JL, Johnson M, Gong G \& Recker RR (1999) Association of VDR and estrogen receptor genotypes with bone mass in postmenopausal Caucasian women: Different conclusions with different analyses and the implications. Osteoporosis International 9, 499-507.

Dick IM, Devine A, Marangou A, Dhaliwal SS, Laws S, Martins RN \& Prince RL (2002) Apolipoprotein E4 is associated with reduced calcaneal quantitative ultrasound measurements and bone mineral density in elderly women. Bone 31, 497-502.

Dohi Y, Iki M, Ohgushi H, Gojo S, Tabata S, Kajita E, Nishino H \& Yonemasu K (1998) A novel polymorphism in the promoter region for the human osteocalcin gene: the possibility of a correlation with bone mineral density in postmenopausal Japanese women. Journal of Bone and Mineral Research 13, 1633-1639.

Eccleshall TR, Garnero P, Gross C, Delmas PD \& Feldman D (1998) Lack of correlation between start codon polymorphism of the vitamin $\mathrm{D}$ receptor gene and bone mineral density in premenopausal French women: The OFELY Study. Journal of Bone and Mineral Research 13, 31-35.

Eisman JA (1995) Vitamin D receptor gene alleles and osteoporosis: an affirmative view. Journal of Bone and Mineral Research 10, 1289-1293.

Eisman JA (1999) Genetics of osteoporosis. Endocrine Reviews 20, 788-804.

Eisman JA (2001) Pharmacogenetics of the vitamin D receptor and osteoporosis. Drug Metabolism and Disposition 29, 505-512.

Ensrud KE, Stone K, Cauley JA, White C, Zmuda JM, Nguyen TV, Eisman JA \& Cummings SR for the Study of Osteoporotic Fractures Research Group (1999) Vitamin D receptor gene polymorphisms and the risk of fractures in older women. Journal of Bone and Mineral Research 14, 1637-1645.

European Commission (1998) Report on Osteoporosis in the European Community: Action for Prevention. Luxembourg: Office for Official Publications for the European Commission.

Ferrari S, Rizzoli R, Chevalley T, Slosman D, Eisman JA \& Bonjour JP (1995) Vitamin D receptor gene polymorphisms and change in lumbar spine bone mineral density. Lancet 345, 423-424.

Ferrari S, Rizzoli R, Manen D, Slosman D \& Bonjour JP (1998) Vitamin D receptor gene start codon polymorphisms (Fok I) and bone mineral density: Interaction with age, dietary calcium, and 3 '-end region polymorphisms. Journal of Bone and Mineral Research 13, 925-930.

Feskanich D, Hunter DJ, Willett WC, Hankinson SE, Hollis BW, Hough HL, Kelsey KT \& Colditz GA (1998) Vitamin D receptor genotype and the risk of bone fractures in women. Epidemiology 9, 535-539.

Francis RM, Harrington F, Turner E, Papiha SS \& Datta HK (1997) Vitamin D receptor gene polymorphism in men and its effect on bone density and calcium absorption. Clinical Endocrinology 46, 83-86.

Garnero P, Borel O, Sornay-Rendu E, Arlot ME \& Delmas PD (1996) Vitamin D receptor gene polymorphisms are not related to bone turnover, rate of bone loss, and bone mass in postmenopausal women: The OFELY Study. Journal of Bone and Mineral Research 11, 827-834.

Genant HK, Cann CE, Ettinger B \& Gordan GS (1982) Quantitative computed tomography of vertebral spongiosa: A sensitive method for detecting early bone loss after oophorectomy. Annals of Internal Medicine 97, 699-705.

Gennari L, Becherini L, Falchetti A, Masi L, Massart F \& Brandi ML (2002) Genetics of osteoporosis: role of steroid hormone receptor gene polymorphisms. Journal of Steroid Biochemistry and Molecular Biology 81, 1-24.

Gennari L, Becherini L, Mansani R, Masi L, Falchetti A, Morelli A, Colli E, Gonnelli S, Cepollaro C \& Brandi ML (1999) Fok I polymorphism at translation initiation site of the vitamin D receptor gene predicts bone mineral density and vertebral fractures in post-menopausal Italian women. Journal of Bone and Mineral Research 14, 1379-1386.

Gennari L, Becherini L, Masi L, Mansani R, Gonnelli S, Cepollaro C, Martini S, Montagnani A, Lentini G, Becorpi AM \& Brandi ML (1998) Vitamin D and estrogen receptor allelic variants in Italian postmenopausal women: Evidence of multiple gene contribution to bone mineral density. Journal of Clinical Endocrinology and Metabolism 83, 939-944.

Gong G, Stern HS, Cheng SC, Fong N, Mordeson J, Deng HW \& Recker RR (1999) The association of bone mineral density with vitamin $\mathrm{D}$ receptor gene polymorphisms. Osteoporosis International 9, 55-64.

Graafmans WC, Lips P, Ooms ME, van Leeuwen JP, Pols HA \& Uitterlinden AG (1997) The effect of vitamin D supplementation on the bone mineral density of the femoral neck is associated with vitamin D receptor genotype. Journal of Bone and Mineral Research 12, 203-205.

Grant SFA, Reid DM, Blake G, Herd R, Fogelman I \& Ralston SH (1996) Reduced bone density and osteoporosis associated with a polymorphic Sp1 site in the collagen type I alpha I gene. Nature Genetics 14, 203-205.

Gross C, Eccleshall TR, Malloy PJ, Villa ML, Marcus R \& Feldman D (1996) The presence of a polymorphism at the translation initiation site of the vitamin $D$ receptor gene is associated with low bone mineral density in post-menopausal Mexican-American women. Journal of Bone and Mineral Research 11, 1850-1855.

Gross C, Krishnan AV, Malloy PJ, Eccleshall TR, Zhao XY \& Feldman D (1998a) The vitamin D receptor gene start codon polymorphism: a functional analysis of Fok1 variants. Journal of Bone and Mineral Research 13, 1-9.

Gross C, Musiol IM, Eccleshall TR, Malloy PJ \& Feldman D (1998b) Vitamin D receptor gene polymorphisms: analysis of ligand binding and hormone responsiveness in cultured skin fibroblasts. Biochemical and Biophysical Research Communications 242, 467-473.

Gueguen R, Jouanny P, Guillemin F, Knutz C, Pourel J \& Siset G (1995) Segregation analysis and variance components analysis on bone mineral density in healthy families. Journal of Bone and Mineral Research 10, 2017-2022.

Han OH, Moon IG, Kang YS, Chung HY, Min HK \& Han IK (1997) Non association of estrogen receptor genotypes with bone mineral density and estrogen responsiveness to hormone replacement therapy in Korean postmenopausal women. Journal of Clinical Endocrinology and Metabolism 82, 991-995. 
Harris SS, Eccleshall R, Gross C, Dawson-Hughes B \& Feldman D (1997) The vitamin D receptor start codon polymorphism (Fok I) and bone mineral density in pre-menopausal American black and white women. Journal of Bone and Mineral Research 12, 1043-1048.

Hassager C, Jensen SB \& Christiansen C (1994) Non-responders to hormone replacement therapy for the prevention of postmenopausal bone loss: Do they exist? Osteoporosis International 4, 36-41.

Hegle RA \& Breslow JL (1987) Apolipoprotein genetic variation in the assessment of atherosclerosis susceptibility. Genetics Epidemiology 4, 163-184.

Heikkinen AM, Kroger H, Niskanen L, Komulainen MH, Tyynanen M, Parviainen MT, Tuppurainen MT, Honkanen R \& Saarikoski S (2000) Does apolipoprotein E genotype relate to $\mathrm{BMD}$ and bone markers in postmenopausal women? Maturitas 34, 33-41.

Hosoi T, Miyao M, Inoue S, Hoshino S, Shirake M, Orimo H \& Ouchi Y (1999) Association study of parathyroid hormone gene polymorphism and bone mineral density in Japanese postmenopausal women. Calcified Tissue International 99, 205-208.

Houston LA, Grant SF, Reid DM \& Ralston SH (1996) Vitamin D receptor polymorphism, bone mineral density, and osteoporotic vertebral fracture: studies in a UK population. Bone 18, 2130-2134.

Institute of Medicine (1997) Dietary Reference Intakes: Calcium, Magnesium, Phosphorus, Vitamin D, and Fluoride. Washington, D.C.: Food and Nutrition Board, National Academy Press.

Institute of Medicine (2001) Dietary Reference Intakes for Vitamin A, Vitamin K, Arsenic, Boron, Chromium, Copper, Iodine, Iron, Manganese, Molybdenum, Nickel, Silicon, Vanadium and Zinc. Washington, DC: National Academy Press.

Ioannidis JPA, Stavrou I, Trikalinos TA, Zois C, Brandi ML, Gennari L, Albagha O, Ralston SH \& Tsatsoulis A (2002) Association of polymorphisms of the estrogen receptor $\alpha$ gene with bone mineral density and fracture risk in women: a metaanalysis. Journal of Bone and Mineral Research 17, 2048-2060.

Jorgensen HL, Madsen JS, Madsen B, Saleh MM, Abrahamsen B, Fenger M \& Lauritzen JB (2002) Association of a common allelic polymorphism (C677T) in the methylenetetrahydrofolate reductase gene with a reduced risk of osteoporotic fractures. A case control study in Danish postmenopausal women. Calcified Tissue International 71, 386-392.

Kiel DP, Myers RH, Cupples LA, Kong XF, Zhu XH, Ordovas J, Schaefer EJ, Felson DT, Rush D, Wilson PWF, Eisman JA \& Holick MF (1997) The BsmI vitamin D receptor restriction fragment length polymorphism (bb) influences the effect of calcium intake on bone mineral density. Journal of Bone Mineral Research 12, 1049-1057.

Kinyamu HK, Gallagher JC, Knezetic JA, DeLuca HF, Prahl JM \& Lanspa SJ (1997) Effect of vitamin D receptor genotypes on calcium abosorption, duodenal vitamin $\mathrm{D}$ receptor concentration and serum 1,25 dihydroxyvitamin D levels in normal women. Calcified Tissue International 60, 491-495.

Kobayashi S, Inoue S, Hosoi T, Ouchi Y, Shiraki M \& Orimo H (1996) Association of bone mineral density with polymorphism of the estrogen receptor gene. Journal of Bone and Mineral Research 11, 306-311.

Korach KS (1994) Insights from the study of animals lacking functional estrogen receptor. Science 266, 1524-1527.

Krall EA, Parry P, Lichter JB \& Dawson-Hughes B (1995) Vitamin $D$ receptor alleles and rates of bone loss: influence of years since menopause and calcium intake. Journal of Bone Mineral Research 10, 978-984.

Kuiper GG, Lemmen JG, Carlsson B, Corton JC, Safe SH, van der Saag PT, van der Burg B \& Gustafsson JA (1998) Interaction of estrogenic chemicals and phytoestrogens with estrogen receptor beta. Endocrinology 139, 4252-4263.

Langdahl BL, Carstens M, Stenkjaer L \& Eriksen EF (2003) Polymorphisms in the transforming growth factor beta 1 gene and osteoporosis. Bone 32, 297-310.

Langdahl B, Lokke E, Carstens M, Stenkjaer L \& Eriksen E (2000) A TA repeat polymorphism in the estrogen receptor gene is associated with osteophorotic fractures but polymorphisms in the first exon and intron are not. Journal of Bone and Mineral Research 15, 2222-2230.

Langdahl BL, Knudsen JY, Jensen HK, Gregersen N \& Eriksen EF (1997) A sequence variation: 713-8delC in the transforming growth factor-beta 1 gene has higher prevalence in osteoporotic women than in normal women and is associated with very low bone mass in osteoporotic women and increased bone turnover in both osteoporotic and normal women. Bone 20, 289-294.

Lau HHL, Ho AYY, Luk KDK \& Kung AWC (2002) Estrogen receptor $\beta$ gene polymorphisms are associated with higher bone mineral density in premenopausal, but not postmenopausal southern Chinese women. Bone 31, 276-281.

Lucotte G, Mercier G \& Burkel A (1999) The vitamin D receptor Fok I start codon polymorphism and bone mineral density in osteoporotic post-menopausal French women. Clinical Genetics 56, 221-224.

Mahley RW, Weisgraber KH, Innerarity TL \& Rall SC Jr (1991) Genetic defects in lipoprotein metabolism. Elevation of atherogenic lipoproteins caused by impaired catabolism. Journal of the American Medical Association 265, 78-83.

Mahonen A, Turunen AM, Kroger H \& Maenpaa PH (1997) Estrogen receptor polymorphism is associated with bone mineral density in perimenopausal Finnish women. Journal of Bone and Mineral Research 12, T614.

Mannz V \& Ralston SH (2003) Meta-analysis of COL1A1 Sp1 polymorphism in relation to bone mineral density and osteoporotic fracture. Bone 32, 711-717.

Masi L, Climaz R, Simonini G, Bindi G, Stagi S, Gozzini A, Malentacchi C, Brandi ML \& Falcini F (2002) Association of low bone mass with vitamin $\mathrm{D}$ receptor gene and calcitonin receptor gene polymorphisms in juvenile idiopathic arthritis. Journal of Rheumatology 29, 2225-2231.

Miyamoto K, Taketani E, Arai E, Yamamoto H, Iemori Y, Chikamori M, Morita K, Takeda E, Tohnai T \& Nishisho T (1996) A novel polymorphism in the vitamin $D$ receptor gene and bone mineral density: Study of vitamin D receptor expression and function in COS-7 cells. Journal of Bone and Mineral Research 11, Suppl., S116.

Miyao M, Morita H, Hosoi T, Kurihara H, Inoue S, Hoshino S, Shiraki M, Yazaki Y \& Ouchi Y (2000) Association of methylenetetrahydrofolate reductase (MTHFR)polymorphism with bone mineral density in postmenopausal Japanese women. Calcified Tissue International 66, 190-194.

Mizunuma H, Hosoi T, Okano H, Soda M, Tokizawa T, Kagami I, Miyamoto S, Ibuki Y, Inoue S, Shiraki M \& Ouchi Y (1997) Estrogen receptor gene polymorphism and bone mineral density at the lumbar spine of pre- and postmenopausal women. Bone 21, 379-383.

Morabito N, Crisafulli A, Vergara C, Gaudio A, Lasco A, Frisina N, D’Anna R, Corrado F, Pizzoleo MA, Cincotta M, Altavilla D, Ientile R \& Squadrito F (2002) Effects of genistein and hormonereplacement therapy on bone loss in early postmenopausal women: a randomized double-blind placebo-controlled study. Journal of Bone and Mineral Research 17, 1904-1912.

Morrison NA, Qi JC, Tokita A, Kelly PJ, Crofts L, Nguyen TV, Sambrook PN \& Eisman JA (1994) Prediction of bone density from vitamin D receptor alleles. Nature 367, 284-287. 
Morrison NA, Qi JC, Tokita A, Kelly PJ, Crofts L, Nguyen TV, Sambrook PN \& Eisman JA (1997) Prediction of bone density from vitamin D receptor alleles. Nature 387, 106.

Mosselman S, Polman J \& Dijkema R (1996) ER- $\beta$ : identification and characterisation of a novel human estrogen receptor. FEBS Letters 392, 49-53.

Murray RE, McGuigan F, Grant SFA, Reid DM \& Ralston SM (1997) Polymorphisms of the interleukin-6 gene are associated with bone mineral density. Bone 21, 89-92.

Nguyen TV, Jones G, Sambrook PN, White CP, Kelly PJ \& Eisman JA (1995) Effects of estrogen exposure and reproductive factors on bone mineral density and osteoporotic fractures. Journal of Clinical Endocrinology and Metabolism 80, 2709-2714.

Norman AW (1990) Intestinal calcium absorption: a vitamin Dhormone-mediated adaptive response. American Journal of Clinical Nutrition 51, 290-300.

Norris RJ (1992) Medical costs of osteoporosis. Bone 13, S11-S12.

Ogawa S, Hosoi T, Shiraki M, Orimo H, Emi M, Muramatsu M, Ouchi Y \& Inoue S (2000) Association of estrogen receptor beta gene polymorphism with bone mineral density. Biochemical and Biophysical Research Communications 269, 537-541.

Ongphiphadhanakul B, Chanprasertyothin S, Payatikul P, Tung SS, Piaseu N, Chailurkit L, Chansirikarn S, Puavilai G \& Rajatanavin R (2000) Oestrogen-receptor-alpha gene polymorphism affects response in bone mineral density to oestrogen in postmenopausal women. Clinical Endocrinology 52, 581-585.

Ongphiphadhanakul B, Rajatanavin R, Chanprasertyothin S, Piaseu N, Chailurkit L, Sirisriro R \& Komind R (1998) Estrogen receptor gene polymorphism is associated with bone mineral density in premenopausal women but not in postmenopausal women. Journal of Endocrinological Investigation 21, 487-493.

Peacock M (1995) Vitamin D receptor alleles and osteoporosis: a contrasting view. Journal of Bone and Mineral Research 10, 1294-1297.

Pluijm SM, Dik MG, Jonker C, Deeg DJ, van Kamp GJ \& Lips P (2002) Effects of gender and age on the association of apolipoprotein E epsilon4 with bone mineral density, bone turnover and the risk of fractures in older people. Osteoporosis International 13, 701-709.

Pocock NA, Eisman JA, Hopper JL, Yeates MG, Sambrook PN \& Eberl S (1987) Genetic determinants of bone mass in adults. A twin study. Journal of Clinical Investigation 80, 706-710.

Potter S, Baum J, Teng H, Stillman R, Shay N \& Erdman J Jr (1998) Soy protein and isoflavones: their effects on blood lipids and bone density in postmenopausal women. American Journal of Clinical Nutrition 68, 1375S-1379S.

Ralston SH (2003) Genetic determinants of susceptibility to osteoporosis. Current Opinion in Pharmacology 3, 286-290.

Rapuri PB, Gallagher JC, Kinyamu HK \& Ryschon KL (2001) Caffeine intake increases the rate of bone loss in elderly women and interacts with vitamin D receptor genotypes. American Journal of Clinical Nutrition 74, 694-700.

Riggs L \& Melton LJ (1986) Involutional osteoporosis. New England Journal of Medicine 314, 1676-1686.

Riis BJ, Thomsen K, Strom V \& Christiansen C (1987) The effect of percutaneous estradiol and natural progesterone on postmenopausal bone loss. American Journal of Obstetrics and Gynecology 156, 61-65.

Salamone LM, Cauley JA, Zmuda J, Pasagian-Macaulay A, Epstein RS, Ferrell RE, Black DM \& Kuller LH (2000) Apolipoprotein E gene polymorphism and bone loss: estrogen status modifies the influence of apolipoprotein $\mathrm{E}$ on bone loss. Journal of Bone and Mineral Research 15, 308-314.

Salamone LM, Glynn NW, Black DM, Ferrell RE, Palermo L, Epstein RS, Kuller LH \& Cauley JA (1996) Determinants of premenopausal bone mineral density: The interplay of genetic and lifestyle factors. Journal of Bone Mineral Research $\mathbf{1 1}$ $1557-1565$.

Salmen T, Heikkinen AM, Mahonen A, Kroger H, Komulainen M, Saarikoski S, Honkanen R \& Maenpaa PH (2000a) Early postmenopausal bone loss is associated with Pvu II estrogen receptor gene polymorphism in Finnish women: effect of hormone replacement therapy. Journal of Bone and Mineral Research 15, $315-321$

Salmen T, Heikkinen A, Mahonin A, Kroger H, Komulainen M, Saarikoski S, Honkanen R \& Maenpaa PH (2000b) The protective effect of hormone-replacement therapy on fracture risk is modulated by estrogen receptor $\alpha$ genotype in early postmenopausal women. Journal of Bone and Mineral Research $\mathbf{1 5}$ 2479-2486.

Sanada M, Nakagawa H, Kodama I, Sakasita T \& Ohama K (1998) Apolipoprotein E phenotype associations with plasma lipoproteins and bone mass in postmenopausal women. Climacteric 1, 188-195.

Sano M, Inoue S, Hosoi T, Ouchi Y, Emi M, Shiraki M \& Orimo H (1995) Association of estrogen receptor dinucleotide repeat polymorphism with osteoporosis. Biochemical and Biophysical Research Communications 217, 378-383.

Saupe J, Shearer MJ \& Kohlmeier M (1993) Phylloquinone transport and its influence on $\gamma$-carboxylation residues of osteocalcin in patients on maintenance haemodialysis. American Journal of Clinical Nutrition 58, 204-208.

Shiekh M, Ramirez A, Emmett M, Santa Ana C \& Fordtran J (1988) Role of vitamin D dependent and vitamin D independent mechanisms in absorption of food calcium. Journal of Clinical Investigation 81, 126-132.

Shiraki M, Shiraki Y, Aoki C, Hosoi T, Inoue S, Kaneki M \& Ouchi Y (1997) Association of bone mineral density and apolipoprotein E phenotype. Journal of Bone Mineral Research 12, 1438-1445.

Simopoulos AP (1995) Genetic variation and nutrition. Nutrition Today 30, 157-167.

Slemenda CW, Christian JC, Williams CJ, Norton JA \& Johnston CC Jr (1991) Genetic determinants of bone mass in adult women; a re-evaluation of the model and the potential importance of gene interaction on heritability estimates. Journal of Bone and Mineral Research 6, 651-657.

Smith EP, Boyd J, Frank GR, Takahasi H, Cohen RM, Specker B, Williams TC, Lubahn DB \& Korach KS (1994) Estrogen resistance caused by a mutation in the estrogenreceptor gene in a man. New England Journal of Medicine 331, 1056-1061.

Sowers M, Willing M, Burns T, Deschenes S, Hollis B, Crutchfield M \& Jannusch M (1999) Genetic markers, bone mineral density and serum osteocalcin levels. Journal of Bone and Mineral Research 14, 1411-1419.

Stevenson JC, Cust MP, Gangar KF, Hillard TC, Lees B \& Whitehead MI (1990) Effects of transdermal versus oral hormone replacement therapy on bone density in spine and proximal femur in postmenopausal women. Lancet 336, 265-269.

Stewart TL \& Ralston SH (2000) Role of genetic factors in the pathogenesis of osteoporosis. Journal of Endocrinology 166, $235-245$.

Stulc T, Ceska R, Horinek A \& Stepan J (2000) Bone mineral density in patients with apolipoprotein E type $2 / 2$ and $4 / 4$ genotype. Physiology Research 49, 435-439.

Takacs I, Speer G, Bajnok E, Tabak A, Nagy Z, Horvath C, Kovacs \& Lakatos P (2002) Lack of association between calcium-sensing receptor gene 'A986' polymorphism and bone mineral density in Hungarian postmenopausal women. Bone $\mathbf{3 0}$, 849-852.

Thompson E (2001) Detection of human genetic linkage: foundations. Theoretical Population Biology 60, 203-213. 
Tofteng CL, Jensen JEB, Abrahamsen B, Odum L \& Brot C (2002) Two polymorphisms in the vitamin $\mathrm{D}$ receptor gene - association with bone mass and 5-year change in bone mass with or without hormone-replacement therapy in postmenopausal women: the Danish osteoporosis prevention study. Journal of Bone and Mineral Research 17, 1535-1544.

Uitterlinden AG, Fang Y, Bergink AP, van Meurs JBJ, van Leeuwen HPTM \& Pols HAP (2002) The role of vitamin D receptor gene polymorphisms in bone biology. Molecular and Cellular Endocrinology 197, 15-21.

Uitterlinden AG, Pols HA, Burger H, Huang Q, Van Daele PL, Van Duijn CM, Hofman A, Birkenhager JC \& Van Leeuwen JP (1996) A large-scale population-based study of the association of vitamin $\mathrm{D}$ receptor gene polymorphisms with bone mineral density. Journal of Bone and Mineral Research 11, 1241-1248.

Uitterlinden AG, Weel AE, Burger H, Fang Y, van Dujin CM, Hofman A, van Leeuwen JP \& Pols HA (2001) Interaction between the vitamin D receptor gene and collagen type I alpha I gene in susceptibility for fracture. Journal of Bone and Mineral Research 16, 379-385.

Vandevyver C, Vanhoof J, Declerck K, Stinissen P, Vandervorst C, Michiels L, Cassiman JJ, Boonen S, Raus J \& Geusens P (1999) Lack of association between estrogen receptor genotypes and bone mineral density, fracture history, or muscle strength in elderly women. Journal of Bone and Mineral Research 14, 1576-1582.

Verbeek W, Gombart AF, Shiohara M, Campbell M \& Koeffler HP (1997) Vitamin D receptor: no evidence for allele-specific mRNA stability in cells which are heterozygous for the Taq 1 restriction enzyme polymorphism. Biochemical and Biophysical Communications 238, 77-80.

Vermeer C, Jie K-SG \& Knapen MHJ (1995) Role of vitamin K in bone metabolism. Annual Reviews in Nutrition 15, 1-22.

Vink JM \& Boomsma DI (2002) Gene finding strategies. Biological Psychology 61, 53-71.
Von Muhlen DG, Barrett-Connor E, Schneider DL, Morin PA \& Parry P (2001) Osteoporosis and apolipoprotein E genotype in older adults: The Rancho Bernardo study. Osteoporosis International 12, 332-335.

Willing M, Sowers M, Aron D, Clark MK, Burns T, Bunten C, Crutchfield M, D'Agostino D \& Jannausch M (1998) Bone mineral density and its changes in white women: Estrogen and vitamin D receptor genotypes and their interaction. Journal of Bone and Mineral Research 13, 695-705.

Windahl SH, Vidal O, Andersson G, Gustafsson JA \& Ohlsson C (1999) Increased cortical bone mineral content but unchanged trabecluar bone mineral density in female $\operatorname{ER} \beta(-/-)$ mice. Journal of Clinical Investigation 104, 895-901.

Wishart JM, Horowitz M, Need AG, Scopacasa F, Morris HA, Clifton PM \& Nordin C (1997) Relations between calcium intake, calcitriol, polymorphisms of the vitamin D receptor gene, and calcium absorption in premenopausal women. American Journal of Clinical Nutrition 65, 798-802.

Wood RJ \& Fleet JC (1998) The genetics of osteoporosis: vitamin $\mathrm{D}$ receptor polymorphisms. Annual Reviews of Nutrition $\mathbf{1 8}$, 233-258.

Yamada Y, Ando F, Niino N \& Shimokata H (2002) Association of a polymophism of the matrix metallproteinase-1 gene with bone mineral density. Matrix Biology 21, 389-392.

Yokoyama K, Shigematsu T, Tsukada T, Ogura Y, Takemoto F, Hara S, Yamada Y, Kawaguchi Y \& Hosoya T (1998) Apa I polymorphism in the vitamin $\mathrm{D}$ receptor gene may affect the parathyroid response in Japanese with end-stage renal disease. Kidney International 53, 454-458.

Zittermann A (2003) Vitamin D in preventive medicine: are we ignoring the evidence? British Journal of Nutrition 89, $552-572$.

Zmuda JM, Cauley JA, Danielson ME, Wolf RL \& Ferrell RE (1997) Vitamin D receptor gene polymorphisms, bone turnover, and rates of bone loss in older African-American women. Journal of Bone and Mineral Research 12, 1446-1452. 